\title{
Screening and Characterization of Antibiotic Producing Organisms from Waste Dump Soil Sample
}

\author{
Chinenye U. Ezebialu1, Ikechukwu B. Awuribeh ${ }^{2}$, Ebere M. Eze ${ }^{3}$, Chigoziri T. Ogu1, \\ Uchechukwu G. Nwankwo", Ruth Asikiya Afunwa ${ }^{5 *}$
}

${ }^{1}$ Department of Applied Microbiology and Brewing, Nnamdi Azikiwe University, Awka, Nigeria

${ }^{2}$ Department of Biological Sciences, Godfrey Okoye University, Enugu, Enugu State, Nigeria

${ }^{3}$ Department of Microbiology, Novena University, Ogume, Delta State, Nigeria

${ }^{4}$ Department of Microbiology, Renaissance University, Ugbawka, Enugu State, Nigeria

${ }^{5}$ Department of Pharmaceutical Microbiology and Biotechnology, Faculty of Pharmaceutical Sciences,

Chukwuemeka Odumegwu Ojukwu University, Igbariam, Anambra State, Nigeria

Email: *missruthus2000@yahoo.com

How to cite this paper: Ezebialu, C.U., Awuribeh, I.B., Eze, E.M., Ogu, C.T., Nwankwo, U.G. and Afunwa, R.A. (2020) Screening and Characterization of Antibiotic Producing Organisms from Waste Dump Soil Sample. Advances in Microbiology, 10, 422-433.

https://doi.org/10.4236/aim.2020.109031

Received: July 16, 2020

Accepted: September 11, 2020

Published: September 14, 2020

Copyright $\odot 2020$ by author(s) and Scientific Research Publishing Inc. This work is licensed under the Creative Commons Attribution International License (CC BY 4.0).

http://creativecommons.org/licenses/by/4.0/

\begin{abstract}
This study was designed to screen and characterize antibiotic producing bacteria and fungi from soil samples from a waste dump site in Enugu. The molecular characterization of the isolates was performed by using Zymo Research Quick-DNA fungi/bacteria miniprep kit. The bacteria isolates were Providencia stuartii, Providencia alcalifaciens. Bacillus sp., Streptococcus sp., Micrococcus sp., and Staphylococcus sp while Aspergillus fumigatus and Aspergillus niger were fungal isolates. The efficacy of the Crude Extract (CE) of the antibiotics produced was tested against species of Staphylococcus aureus and Escherichia coli. The CE of antibiotics when compared with a conventional antibiotic (Ciprofloxacin) showed lower antimicrobial activity. The minimum inhibitory concentration of the crude extracts ranged between $12.5 \%$ and $25 \%$ concentrations while the minimum bactericidal concentration ranged from $25 \%$ and $50 \%$ concentrations. The findings suggest that these organisms have the potential to produce antibiotics and could be harnessed by pharmaceutical industries for the production of newer antibiotics.
\end{abstract}

\section{Keywords}

Antibiotics, Crude Extract, Ciprofloxacin, Soil Sample

\section{Introduction}

Soil is a complex and diverse environment harbouring different species of anti- 
biotic producing organisms [1]. About $60 \%$ nearly 500 antibiotics discovered yearly were obtained from the soil [2]. Screening of soil for antimicrobial activities is seen to have been carried out in many parts of the world through analysis [3]. Series of natural products have been identified and developed as therapeutic agents against many infectious diseases [4] yet microbial metabolites still appear as the most promising sources of antibiotics in the future [5] [6]. Antibiotics are part of secondary metabolites produced by microorganisms though the production of antibiotics is enhanced in the presence of optimum temperature, $\mathrm{pH}$, carbon source concentration, and Sodium nitrate concentration. Some important antibiotic producing microorganisms such as Streptomyces, Bacillus, Cephalosporium, and Penicillium have been studied extensively and are still being studied for antibiotic production [7]. Actinomycetes are well known sources of biologically active microbial products, and also most medically and commercially important antibiotics [8] but bacteria and fungi [9] are currently gaining attention in the discovery of new antibiotics

The introduction of newer class of antibiotics of microbial origin has slowed down in the past thirty years [10] [11] yet there are so many microorganisms in the soil that if screened may be potential antibiotic producers. Also, the recent global rise in antibiotic resistance and its spread across the globe which may be due to movement of hosts or contaminated products between locations has been documented [12]. This overwhelming antibiotic resistance to already existing antibiotics and reduced production of newer antibiotics calls for research on other potential antibiotic producing microorganisms, hence the reason for this research.

The objectives of this research were to screen a waste dump site for antibiotic producing bacteria and fungi, produce antibiotics from the isolated antibiotic producing bacteria and fungi, use their crude extracts against pathogenic Gram negative-Escherichia coli and Gram positive-Staphylococcus aureus bacteria, compare the activities of the crude extracts against commercially produced antibiotics-Ciprofloxacin and characterize the isolates using molecular methods.

\section{Materials and Methods}

\section{Sample Site/Collection}

Soil samples were collected from a waste dump site in Phase six (6) area of Trans Ekulu in Enugu $\left(6^{\circ} 27^{\prime} 10^{\prime \prime} \mathrm{N} 7^{\circ} 30^{\prime} 40^{\prime \prime} \mathrm{E}\right)$, Nigeria. The area is a suburb with dense population most of whom are in the lower middle and lower class strata. The dump site was chosen because we expected more microbial association, competition and succession. The area also serves as a commercial centre with a hub of high patronage of small and petty businesses. The sample was collected with the crust and depth of at least 6 inches with the help of sterile spatula and placed in sterile plastic bags for transportation to Microbiology laboratory.

Test Organisms: Two test organisms Staphylococcus aureus and Escherichia coli were collected from stock culture in Microbiology laboratory of Godfrey 
Okoye University, Enugu. They were prepared with a density equivalent to 0.5 Macfarland turbidity standards.

\section{Culturing and Identification of Organisms from the Soil Sample}

A 10-fold serial dilution of the soil sample was done and a $0.1 \mathrm{ml}$ of the suspension was inoculated into freshly prepared nutrient media (Nutrient Agar and Potato Dextrose Agar) using a glass spreader in duplicates. The plates were properly labeled and incubated in an inverted position for 24 hours at $37^{\circ} \mathrm{C}$ for bacteria and at $28^{\circ} \mathrm{C}$ for 3 to 5 days for fungi.

The resulting colonies in the nutrient agar medium after the incubation were sub-cultured on fresh nutrient agar plates using wire loop by streaking followed by incubation for 24 hours at $37^{\circ} \mathrm{C}$. For fungi, each distinct colony on potato dextrose agar plates was further inoculated on fresh potato dextrose agar plates followed by incubation at $28^{\circ} \mathrm{C}$ for 3 to 5 days. Each discrete colony from the pure culture was stored in an agar slant for further analysis and identification.

\section{Biochemical Tests}

Other biochemical analysis such as Gram staining, spore staining, IMViC tests, catalase test, coagulase test, sugar fermentation tests, urease test, oxidase test and citrate utilization test were performed for proper identification of bacterial isolates. Fungal isolates were identified by using slide culture technique.

\section{Molecular Identification of Bacterial and Fungal Isolates}

Genomic DNA from the isolates was extracted by using Zymo Research Quick-DNA (Fungal/Bacteria Miniprep kit (cat. D6005). This was done according to the manufacturer's instruction. A 1\% (w/v) Agarose gel Electrophoresis was prepared for checking the quality of the extracted DNA samples. Polymerase Chain reaction (PCR) amplification reactions were performed in a GeneAmp ${ }^{\circ}$ PCR System 9700, Applied Biosystems for 36 cycles as follows: Initial denaturation step of $94^{\circ} \mathrm{C}$ for 5 minutes, denaturation step of 30 seconds at $94^{\circ} \mathrm{C}$, annealing step of $56^{\circ} \mathrm{C}$ for 30 seconds, extension step of $72^{\circ} \mathrm{C}$ for 45 seconds and final extension step of $72^{\circ} \mathrm{C}$ for 7 minutes. PCR amplicons were loaded on $1.5 \%$ agarose gel and run at 100 volts for 40 minutes. The ladder used was $1 \mathrm{~kb}$ DNA ladder from New England Biolab.

\section{PCR Product Purification}

A $20 \mu \mathrm{l}$ of absolute ethanol was added to the PCR tubes and incubated at room temperature for 15 minutes, followed by spinning down at 10,000 rpm for 15 minutes. After which the supernatant was decanted and spin down at 10,000 rpm for 15 minutes. A 2 vol ( $40 \mathrm{ul}$ ) of $70 \%$ ethanol was added to the PCR tubes followed by decanting of supernatant and air drying. After the air drying, $10 \mathrm{ul}$ of ultrapure water was added to the PCR tubes. Presence of amplicon was checked on $1.5 \%$ agarose gel.

\section{Sequencing}

The amplicons with single band were selected from the amplified products and purified by using manufacturer's protocol (QIAquick PCR Purification Kit, cat. No.28106). Sequencing was performed by using a Big Dye terminator sequencing kit (Applied BioSystems), Unincorporated dye terminators were then 
purified and precipitated by using ethanol EDTA solution. The pellets were then re-dissolved in HiDiformamide buffer (Applied Biosystems Cat No. 4311320). Sequencing was performed by using 3130xl Genetic Analyser.

\section{Data Analysis}

The sequencing results generated were uploaded in the blue line of DNA Subway (https://dnasubway.cyverse.org/), which is an intuitive interface for analysing DNA barcodes. Using the Blue Line, the assembled sequences were end-trimmed, paired in their respective forward and reverse sequences to build consensus sequences. Sequence alignment and percentage similarity searches were compared with Genbank database using NCBI web-based site, BLAST.

\section{Antimicrobial Susceptibility Testing}

The antimicrobial susceptibility testing of the isolates were determined by agar well diffusion method using Mueller Hinton agar with an inoculum density equivalent to 0.5 Macfarland turbidity standards of the test organisms, E. coli and $S$. aureus. The inoculum density is equivalent to $1.5 \times 10^{8}$ bacteria per $\mathrm{ml}$.

Production Medium for Antimicrobial Compounds: The antibiotic production media for bacteria and fungi were prepared as described by [13] and sterilized. The inoculums were prepared differently for bacteria and fungi as described by [13] and were added to the production medium. Antibiotic production was done by using shake flask fermentation method. That of bacteria was incubated in the shaker for 24 hours while that of fungi was for 7 days. Purification of the antibiotic medium was done after the incubation by process of centrifugation at $4000 \mathrm{rpm}$ for 10 minutes and the cell free supernatant (crude extract) was used for the antimicrobial assay.

Comparing Antimicrobial Activity of the Crude Extracts with the Conventional Antibiotic Sold in the Market

Agar well diffusion method was used to check the cultures for the production of antimicrobial metabolites. Twenty-four hours fresh cultures of one Gram positive Staphylococcus aureus and one Gram-negative Escherichia coli were diluted with pre-sterilized normal saline to obtain a 0.5 MacFarland standard. A sterilized rod spreader was dipped in the diluted cultures and lawns were prepared over the agar surface.

Wells were made in the inoculated plates by using sterile cork borer. $0.2 \mathrm{ml}$ of cell free supernatants was added in the wells and $0.2 \mathrm{ml}$ of diluted conventional ciprofloxacin was added in a well and the plates were incubated at $37^{\circ} \mathrm{C}$ for 24 hours. After 24 hours, the zones of inhibition were observed. The diameter of the zone of inhibition was measured in $\mathrm{mm}$ with well size of $8 \mathrm{~mm}$.

Determination of Minimum Inhibitory Concentration (MIC)

The MIC helps to measure more exactly the minimum concentration of antibiotic necessary to inhibit growth of a microorganism under defined conditions. The MIC was determined by the lowest concentration that inhibited the growth of the organisms. The MIC was determined by broth dilution method using Mueller Hinton broth. Five test tubes containing $2 \mathrm{ml}$ of Mueller Hinton broth 
were prepared for two fold serial dilution. After autoclaving and cooling, $1 \mathrm{ml}$ of the standardized test organism was inoculated into all the four test tubes. A $1 \mathrm{ml}$ of the antibiotic containing cell free supernatant was pipetted into the first test tubes containing $1 \mathrm{ml}$ of Mueller Hinton broth to obtain a $50 \%$ concentration. Subsequent serial dilution was done to obtain a dilution of $25 \%, 12.5 \%$ and $6.25 \%$ concentrations.

\section{Determination of Minimum Bactericidal Concentration (MBC)}

The $\mathrm{MBC}$ is the lowest concentration of the antimicrobial agent that kills the test organisms. A drop from each concentration test tube of the MIC were streaked on a prepared plate and allowed to incubate for 24 hours at $37^{\circ} \mathrm{C}$. The $\mathrm{MBC}$ result was read after $24 \mathrm{~h}$

\section{Results}

\section{Identification of Bacteria and Fungi Isolates}

Seven bacterial and three fungal species were isolated from the soil sample using morphological, biochemical characteristics. Only six of the isolates that showed the ability to produce antibiotics were sent for molecular identification. Three of the Gram negative isolates were identified as Providencia. One Gram positive rod that was suspected to be a member of Bacillus species using morphological and biochemical characteristics was not identified molecularly because of poor sensitivity. Two of the fungal isolates were Aspergillus niger and one was Aspergillus fumigatus (Table 1 and Table 2).

Table 1. Morphological and biochemical characteristics of bacterial Isolates.

\begin{tabular}{|c|c|c|c|c|c|c|c|}
\hline Test & $\begin{array}{c}\text { NS2 } \\
\text { (Providencia } \\
\text { stuartii) }\end{array}$ & $\begin{array}{c}\text { NS4 }{ }_{\mathrm{D}} \\
\text { (Providencia } \\
\text { alcalifaciens) }\end{array}$ & $\begin{array}{l}\mathrm{NS4}_{\mathrm{G}}(\mathrm{PS}) \\
\text { Bacillus } s p\end{array}$ & $\begin{array}{c}\text { NS4y } \\
\text { (Providencia } \\
\text { alcalifaciens) }\end{array}$ & $\begin{array}{c}\text { NS4w } \\
\text { (Streptococcus } \\
s p .)\end{array}$ & $\begin{array}{c}\text { NS4}_{\mathrm{B}} \\
\text { (Micrococcus } \\
s p .)\end{array}$ & $\begin{array}{c}\text { NS3 } \\
\text { (Staphylococcus } \\
\text { sp.) }\end{array}$ \\
\hline Gram's reaction & - & - & + & - & + & + & + \\
\hline Cell shape & Small rods & Short rods & Short rod & Small rods & Cocci in chains & $\begin{array}{l}\text { Cocci in short } \\
\text { chains }\end{array}$ & Cocci cluster \\
\hline Colony characteristics & Dull & Dull & Yellow & Dull & White & Yellow & Yellow \\
\hline Spore & - & - & + & - & - & - & - \\
\hline Indole & + & - & + & + & - & - & - \\
\hline Coagulase & - & - & - & - & - & - & + \\
\hline Catalase & + & + & + & + & - & + & + \\
\hline Oxidase & - & - & - & - & - & - & - \\
\hline Urease & + & + & + & + & + & - & + \\
\hline Starch hydrolysis & + & + & + & + & + & + & + \\
\hline Glucose & A & A & A & A & A & A & A \\
\hline Lactose & A & AG & G & A & A & A & AG \\
\hline Mannitol & AG & AG & AG & AG & AG & AG & AG \\
\hline
\end{tabular}

Keys: + Positive; - Negative: $\mathrm{A}$ = acid, $\mathrm{G}=$ gas, $\mathrm{AG}=$ acid + gas. 
Table 2. Identification of fungal Isolates.

\begin{tabular}{|c|c|c|c|}
\hline Test & EF (Aspergillus niger) & GF (Aspergillus fumigatus) & BF (Aspergillus niger) \\
\hline Colour & Slightly brown & Gray & Slightly brown \\
\hline Size & Very large & Large & Very large \\
\hline Microscopy & $\begin{array}{l}\text { Pale brown or hyaline conidiophores usually } \\
\text { simple, erect, thick walled, with basally foot cells, } \\
\text { globose vesicles. Composed of catenulate conidia } \\
\text { uniseriate or biseriatephialides on vesicles and } \\
\text { phialides acutely tapered at apex. Conidia are single } \\
\text { celled, phialosporous, black in mass, minutely } \\
\text { echinulate. }\end{array}$ & $\begin{array}{l}\text { Uniseriate pyriform, glubose } \\
\text { small in column, smooth or } \\
\text { spinose conidia. }\end{array}$ & $\begin{array}{l}\text { Pale brown or hyaline conidiophores } \\
\text { usually simple, erect, thick walled, with } \\
\text { basally foot cells, globose vesicles. } \\
\text { Composed of catenulate conidia uniseriate } \\
\text { or biseriatephialides on vesicles and } \\
\text { phialides acutely tapered at apex. Conidia } \\
\text { are single celled, phialosporous, black in } \\
\text { mass, minutely echinulate. }\end{array}$ \\
\hline
\end{tabular}

\section{Molecular Characterization}

BLAST Analysis of the Sequences Generated from the Bacteria and Fungi Isolates

Four (4) suspected different bacterial isolates were selected for molecular characterization from the seven (7) isolated bacteria from soil. The DNA was successfully isolated from the suspected isolates after which the extracted DNA was used for polymerase chain reaction (PCR). The success of the PCR was confirmed by agarose gel electrophoresis and all amplicons produced a band of approximately $850 \mathrm{bp}$ which is expected for the amplified gene. The result of the sequence analysis showed that out of the four samples selected, three sequences were of high quality (Providencia staurtii, Providencia alcalifaciens and Providencia alcalifaciens) while one was of low quality (Bacillus sp.). The three sequence samples with high quality sequence were identified by using web base blast tool of National Center for Biotechnology Information (NCBI). All sequences aligned with different sequences in the gene bank with varying percent identity while e-value was zero for all.

The result of the sequence analysis of the three fungal isolates sequenced showed high quality and were identified as Aspergillus niger, Aspergillus fumigatus and Aspergillus niger by using web base blast tool of National Center for Biotechnology Information. The output of the BLAST query of the sequences produced significant hits and all seven sequences were identified (Table 3 ). The percentage identity ranged from $93 \%$ - 99\%, total bit score obtained in all ranged from 1101 - 11,667 for the bacteria isolates sequence while the percentage identity for the fungi isolates sequence ranged from $91 \%-100 \%$, total bit score obtained in all the sequence ranged from $843-1110$. The query coverage spanned between $99 \%$ and $100 \%$ while the e-value for all sequence was zero for both bacteria and fungi isolates.

\section{Primary Screening of the Isolates for Antimicrobial Activity}

Out of the 7 bacterial isolates, only four showed zones of inhibition when used against the test organisms $-S$. aureus and $E$. coli at primary screening (Table 4). These four including 3 species of providencia and the suspected Bacillus specie were used for antibiotic production because they showed positive antibiotic activity. 
Table 3. BLAST outputs of total score, query coverage, e-value, percentage identity and accession number obtained from the isolates' sequence.

\begin{tabular}{|c|c|c|c|c|c|c|c|}
\hline $\begin{array}{l}\text { Sample } \\
\text { IDs }\end{array}$ & $\begin{array}{c}\text { Sequence } \\
\text { length (bp) }\end{array}$ & $\begin{array}{l}\text { Top Hit from } \\
\text { NCBI database }\end{array}$ & $\begin{array}{c}\text { Accession } \\
\text { No }\end{array}$ & $\begin{array}{c}\text { Query } \\
\text { coverage }\end{array}$ & E-value & $\begin{array}{c}\% \\
\text { Identity }\end{array}$ & $\begin{array}{l}\text { Total } \\
\text { score }\end{array}$ \\
\hline NS2 & 941 & $\begin{array}{c}\text { Providencia } \\
\text { stuartii }\end{array}$ & СР031508 & 99 & 0 & 98.74 & 11,667 \\
\hline $\mathrm{NS}_{\mathrm{D}}$ & 744 & $\begin{array}{l}\text { Providencia } \\
\text { alcalifaciens }\end{array}$ & MH1661805 & 99 & 0 & 93.055 & 1101 \\
\hline $\mathrm{NS}_{\mathrm{G}}$ & PS & PS & PS & PS & PS & PS & PS \\
\hline $\mathrm{NS} 4_{\mathrm{Y}}$ & 928 & $\begin{array}{l}\text { Providencia } \\
\text { alcalifaciens }\end{array}$ & HQ407246 & 100 & 0 & 99.04 & 1670 \\
\hline $\mathrm{EF}$ & 602 & $\begin{array}{l}\text { Aspergillus } \\
\text { niger }\end{array}$ & MG991648 & 100 & 0 & 99.67 & 1105 \\
\hline GF & 601 & $\begin{array}{l}\text { Aspergillus } \\
\text { fumigatus }\end{array}$ & JX501388 & 100 & 0 & 91.51 & 84 \\
\hline $\mathrm{BF}$ & 601 & $\begin{array}{l}\text { Aspergillus } \\
\text { niger }\end{array}$ & MG991652 & 100 & 0 & 100.00 & 1110 \\
\hline
\end{tabular}

PS $=$ Poor sequence.

Table 4. Primary screening of the isolates for antibiotic production against the test organisms.

\begin{tabular}{ccc}
\hline Isolates & S. aureus & $E$. coli \\
\hline Providencia stuartii & + & + \\
Providencia alcalifaciens & + & + \\
Bacillus sp. & + & + \\
Providencia alcalifaciens & + & - \\
Streptococcus sp. & - & - \\
Micrococcus sp. & - & + \\
Staphylococcus sp & - & + \\
Aspergillus niger & + & + \\
Aspergillus fumigatus & + & +
\end{tabular}

Key: +: showed activity against the test organisms; -: did not show any activity against the test organisms.

Of the three fungal isolates, two Aspergillus niger and the Aspergillus fumigatus showed zones of inhibition against the test organisms-S. aureus and $E$. coli (Table 4). The isolates were used for antibiotic production

\section{Secondary Screening of the Crude Antibiotics after Production}

The produced antibiotics from two Providencia species ( $\mathrm{PS}$ and $\mathrm{PA}_{2}$ ) and the suspected Bacillus (BA) species showed antibiotic activity against the test organisms. The first Providencia alcalifaciens $\left(\mathrm{PA}_{1}\right)$ did not show any activity against the test organisms (Table 5).

The crude antibiotics from two fungal isolates showed activity only against the test organism Escherichia coli (Table 5). 
Table 5. Secondary screening of the antibiotics.

\begin{tabular}{cccc}
\hline & & \multicolumn{2}{c}{$\begin{array}{c}\text { Zones of inhibition (mm) of } \\
\text { the isolates against the test bacteria }\end{array}$} \\
\hline Isolates & Antibiotic label & S. aureus & E. coli \\
Providencia stuartii. & $\mathrm{PS}$ & $\mathbf{1 4}$ & 14 \\
Providencia alcalifaciens. & $\mathrm{PA}_{1}$ & - & - \\
Bacillus species & $\mathrm{BA}$ & 10 & 18 \\
Providencia alcalifaciens & $\mathrm{PA}_{2}$ & 12 & 17 \\
Aspergillus fumugatus & $\mathrm{AF}$ & - & 18 \\
Aspergillus niger & $\mathrm{AN}$ & - & 12 \\
\hline
\end{tabular}

Keys: -: did not show any zone of inhibition against the test organisms.

Comparing the Antibacterial Activity of the Crude Antibiotics from the Bacterial and Fungal Isolates with That of Conventional Antibiotics

The conventional antibiotics (Ciprofloxacin, Pharmabase Nig. Ltd) showed higher antibacterial activity than the antibiotics produced from the isolates (Figure 1 and Figure 2).

\section{Minimum Inhibitory Concentration (MIC) of the Antibiotics}

The crude antibiotic produced from the bacterial isolates showed their Minimum Inhibitory Concentration at $25 \%$ concentration after 24 hours of incubation at $37^{\circ} \mathrm{C}$. The crude antibiotics produced from fungal isolates showed minimum inhibitory concentration on only E. coli at $12.5 \%$ and $25 \%$ concentration for Aspergillus fumigatus and Aspergillus niger respectively after 24 hours of incubation (Table 6). Culturing the MIC tubes into fresh Mueller Hinton agar to check for MBC yielded growth of the test isolates after 24 hours of incubation (Table 7)

\section{Discussion}

The bacterial isolates: Providencia stuartii, Providencia alcalifaciens, Providencia alcalifaciens. Bacillus sp., Stretococcus sp., Micrococcus sp., and Staphylococcus $s p$ and the fungal isolates: Aspergillus niger, Aspergillus fumigatus and Aspergillus niger have also been recovered by other researchers [3] [14] [15]. The fungi identification highlights the importance of correct identification and taxonomical differentiation between different species of Aspergillus [16] [17] [18] [19]. Members of the Providencia are components of the normal bacterial flora of the intestinal tracts of humans and animals and are widespread in the environment. Providencia species being members of enterobacteriaceae are known to colonize the intestine and have been found in urine, faeces, catheters and skins of patients [20]. Identification of these microorganisms in soil may be as a result of the study site-waste dump which may also harbor faeces of humans due to poor sanitary conditions associated with such areas. Bacillus species are well known soil dwellers [14] and that was also in line with our findings though we were not able to identify our Bacillus species molecularly because of poor sequencing, possibly due to denaturation of the DNA. 


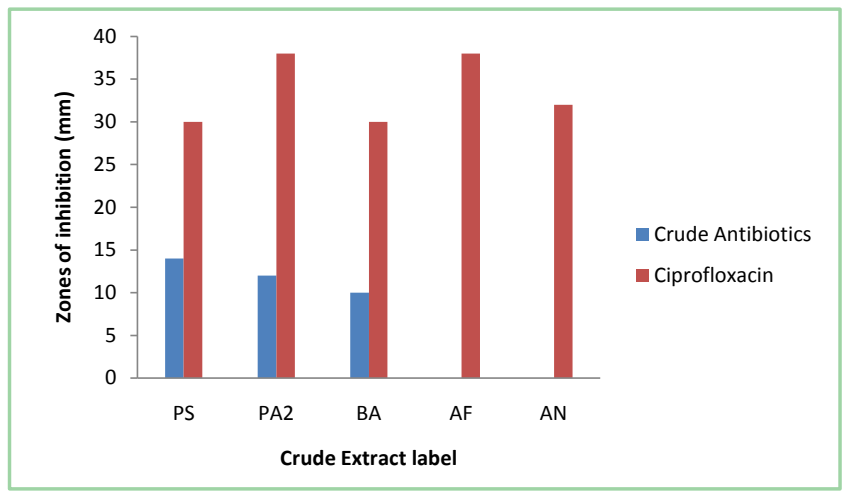

Figure 1. Comparing the activities of antibiotics produced from the microorganisms against conventional ciprofloxacin on Staphylococcus aureus.

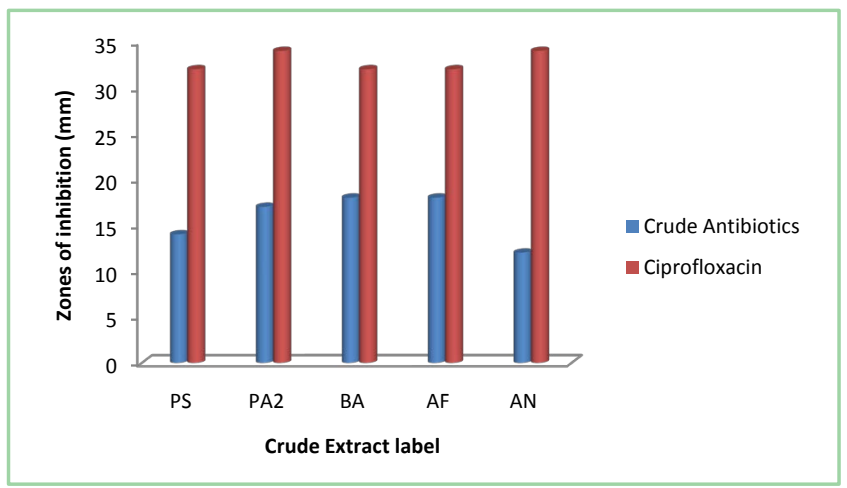

Figure 2. Comparing the activities of antibiotics produced from the microorganisms against conventional ciprofloxacin on Escherichia coli.

Table 6. Minimum Inhibitory Concentration (MIC) of antibiotics produced.

\begin{tabular}{ccc}
\hline \multirow{2}{*}{ Antibiotics producing microorganisms } & \multicolumn{2}{c}{ Minimum inhibitory concentration (MIC) (\%) } \\
\cline { 2 - 3 } & S. aureus & E. coli \\
\hline Providencia stuartii & 25 & 25 \\
Bacillus sp. & 25 & 25 \\
Providencia alcalifaciens & 25 & 25 \\
Aspergillus fumigatus & - & 12.5 \\
Aspergillus niger & - & 25
\end{tabular}

Key: -: not tested.

Table 7. Minimum Bactericidal Concentration (MBC) of the antibiotics produced.

\begin{tabular}{ccc}
\hline \multirow{2}{*}{ Antibiotics producing microorganisms } & \multicolumn{2}{c}{$\begin{array}{c}\text { Minimum bactericidal concentration } \\
(\mathrm{MBC})(\%)\end{array}$} \\
\cline { 2 - 3 } & S. aureus & E. coli \\
\hline Providencia stuartii & 50 & 50 \\
Bacillus sp. & 50 & 50 \\
Providencia alcalifaciens & 50 & 50 \\
Aspergillus fumigatus & - & 25 \\
Aspergillus niger & - & 50 \\
\hline
\end{tabular}

Key: -: not tested. 
The bacterial and fungal isolates from the soil sample (waste polluted soil) showed antibiotic activity and were found to inhibit Gram positive as well as Gram-negative organisms. Antibiotic production from Bacillus species has been recorded by [14] who screened soil microorganisms for antibiotic production and revealed that only Bacillus species exhibited antibacterial activity of all bacteria isolated. For the synthesis of secondary metabolites Bacillus species are well known to produce antibiotics such as polymyxin and bacitracin. Providencia species have not been known for antibiotic production but they exhibited some potential in this work. This also calls for further research.

Two fungal isolates Aspergillus fumigatus and Aspergillus niger were also isolated from the soil with its activity only against the Gram-negative test organism. In a study by [3] they screened fungal isolates from soil for antibiotic production and found out that E. coli was inhibited by Rhizopus stolonifera and Aspergillus fumigatus. Svahn et al. [15] recognized 61 strains of filamentous fungi which were identified as Aspergillus specie. Majority of the Aspergillus strains shows antibiotic activity against beta lactamase producing $E$. coli, methicillin-resistant S. aureus, Enterococcus faecalis and Candida albicans. Miyake et al. [21] and Gugnani [16] also reported other applications of Aspergillus species in the production of antioxidants and industrial enzymes.

Ciprofloxacin, a broad-spectrum conventional antibiotic used as a control showed higher antibacterial activity than the crude antibiotic extracts produced by the isolates. This may be because the antibiotics are still in the crude form and not yet purified as the presence of other compounds may interfere with the drug's antimicrobial activity. This may also be the reason for the loss of antibacterial activity after primary screening of one of the Providencia alcalifaciens crude extract.

The outcome of the minimum inhibitory and bactericidal concentrations carried out suggests that the crude antibiotics extracts may be bacteriostatic at lower concentration and bactericidal at higher concentrations.

\section{Conclusion}

The bacterial and fungal isolates from waste dump in Enugu include Providencia stuartii, Providencia alcalifaciens, Providencia alcalifaciens. Bacillus sp., Stretococcus sp., Micrococcus sp., and Staphylococcus sp, Aspergillus niger, Aspergillus fumigatus and Aspergillus niger. The crude antibiotics extracts produced from some of the isolates showed that they possess antibiotic producing ability. Antibiotic production was unusually recorded for Providencia species which calls for further research.

\section{Funding}

No grant or funding was received for this research.

\section{Conflicts of Interest}

The authors declare no conflicts of interest regarding the publication of this paper. 


\section{References}

[1] Baltz, R.H. (2006) Marcel Faber Roundtable: Is Our Antibiotic Pipeline Unproductive Because of Starvation, Constipation or Lack of Inspiration? Journal of Industrial Microbiology and Biotechnology, 33, 507-513. https://doi.org/10.1007/s10295-005-0077-9

[2] Molinari, G. (2009) Natural Products in Drug Discovery, Present Status and Perspectives. Pharmaceutical Biotechnology, 655, 13-27. https://doi.org/10.1007/978-1-4419-1132-2 2

[3] Makut, M. and Owolewa, O. (2011) Antibiotic-Producing Fungi Present in the Soil Environment of Keffi Metropolis, Nasarawa State, Nigeria. Trakia Journal of Sciences, 9, 33-39.

[4] Berdy, J. (2005) Bioactive Metabolites, a Personal View. Journal of Antibotics, 58, 1-26. https://doi.org/10.1038/ja.2005.1

[5] Fernando, P. (2006) The Historical Delivery of Antibiotics from Microbial Natural Products-Can History Repeat? Biochemical Pharmacology, 71, 981-990. https://doi.org/10.1016/j.bcp.2005.10.010

[6] Wohlleben, W., Mast, Y., Stegmann, E. and Ziemert, N. (2016) Antibiotic Drug Discovery. Microbial Biotechnology, 9, 541-548. https://doi.org/10.1111/1751-7915.12388

[7] Brock, T.D. and Madigan, M.T. (1991) Biology of Microorganisms. 6th Edition, Prentice-Hall International Incorporated, USA, 198-223.

[8] Adegboye, M.F. and Babalola, O.O. (2013) Actinomycetes: A Yet Inexhaustive Source of Bioactive Secondary Metabolites. In: Mendez-Vilas, A., Ed., Microbial Pathogens and Strategies for Combating Them: Science, Technology and Education, Formatex, Nassarawa State, 786-795.

[9] Bhardwaj, A., Chaman, S. and Verma, S. (2017) Production of Antibacterial Agent from Fungi Isolated from Pharmaceutical Soil Sample by Fermentation under Optimized Conditions. Asian Journal of Pharmaceutical and Clinical Research, 10, 110-115. https://doi.org/10.22159/ajpcr.2017.v10i7.18258

[10] Coates, A.R., Halls, G. and Hu, Y. (2011) Novel Classes of Antibiotics or More of the Same? British Journal of Pharmacology, 163, 184-194. https://doi.org/10.1111/j.1476-5381.2011.01250.x

[11] Laxminarayan, R. (2014) Antibiotic Effectiveness: Balancing Conservation against Innovation. Science, 345, 1299-1301. https://doi.org/10.1126/science.1254163

[12] Wernli, D., Haustein, T., Conly, J., Carmeli, Y., Kickbusch, I. and Harbarth, S. (2011) A Call for Action: The Application of the International Health Regulations to the Global Threat of Antimicrobial Resistance. PLoS Medicine, 8, e1001022. https://doi.org/10.1371/journal.pmed.1001022

[13] Sethi, S., Kumar, R. and Gupta, S. (2013) Antibiotic Production by Microbes Isolated from Soil. International Journal of Pharmaceutical Sciences and Research, 4, 2967.

[14] Ahmed, R.N., Sani, A.H., Ajijolakewu, and Alamu, F.B. (2013) Soil Screening for Antibioti-Producing Microorganisms. Advances in Environmental Biology, 7, 7-11

[15] Svahn, S.K., Goransson, U., El-Seed,i H., Bohlin, L., Larsson, J.D.G., Olsen, B. andChryssanthou, E. (2012) Antimicrobial Activity of Filamentous Fungi Isolated from Highly Antibiotic Contaminated River Sediment. Infection, Ecology and Epidemiology, 2, 11591. https://doi.org/10.3402/iee.v2i0.11591

[16] Gugnani, H. (2003) Ecology and Taxonomy of Pathogenic Aspergilli. Frontiers in 
Bioscience, 8, s346-s357.

[17] Noonimabc, P., Mahakarnchanakulb, W., Nielsend, K.F., Frisvadd, J.C. and Samsona, R.A. (2009) Fumonisin B2 Production by Aspergillus niger in Thai Coffee Beans. Food Additives \& Contaminants, 26, 94-100.

https://doi.org/10.1080/02652030802366090

[18] Palencia, E.R., Hinton, D.M. and Bacon, C.W. (2010) The Black Aspergillus Species of Maize and Peanuts and Their Potential for Mycotoxin Production. Toxins, 2, 399-416. https://doi.org/10.3390/toxins2040399

[19] Gautam, A.K., Sharma, S., Avasthi, S. and Bhadauria, R. (2011) Diversity, Pathogenicity and Toxicology of A. niger. An Important Spoilage Fungi. Research Journal of Microbiology, 6, 270-280. https://doi.org/10.3923/jm.2011.270.280

[20] O’Hara, C.M., Brenner, F.W. and Miller, M.J. (2000) Classification, Identification, and Clinical Significance of Proteus, Providencia, and Morganella. Clinical Microbiology Reviews, 13, 534-546. https://doi.org/10.1128/CMR.13.4.534

[21] Miyake, Y., Ito, C, Itoigawa, M. and Osawa, T. (2007) Isolation of the Antioxidant Pyranonigrin-A from Rice Mold Starters Used in the Manufacturing Process of Fermented Foods. Bioscience, Biotechnology, and Biochemistry, 71, 2515-2521. https://doi.org/10.1271/bbb.70310 